\title{
APLIKASI TEKNOLOGI PENGERING KACANG TANAH DI DESA KINALI SATU KECAMATAN KAWANGKOAN KABUPATEN MINAHASA
}

\author{
Revolson A. Mege1, Grace J. Soputan², Jemmy Kewas' ${ }^{3}$, Wensi Paat ${ }^{3}$, \& \\ Jeane Mantiri ${ }^{4}$ \\ ${ }^{1}$ Fakultas Matematika dan Ilmu Pengetahuan Alam, Universitas Negeri Manado \\ ${ }^{2}$ Fakultas Ekonomi, Universitas Negeri Manado \\ ${ }^{3}$ Fakultas Teknik, Universitas Negeri Manado \\ ${ }^{4}$ Fakultas Ilmu Sosial, Universitas Negeri Manado \\ ramege@unima.ac.id
}

\begin{abstract}
Abstrak
Suatu kegiatan deseminasi produk teknologi kepada masyarakat telah dilaksanakan bertujuan untuk mengaplikasikan teknologi pengeringan dan pengemasan kacang tanah dalam upaya meningkatkan kualitas produk olahan kacang tanah khususnya kacang sangrai. Target luaran dari program deseminasi produk teknologi kepada masyarakat ini adalah (1) memfasilitasi tersedianya teknologi pengolahan kacang tanah (mesin pengering) kacang tanah, (2) memfasilitasi upaya peningkatan penguasaan pengetahuan dan teknologi serta keterampilan masyarakat dalam proses pengeringan dan pengemasan yang memenuhi standar kualitas dan kesehatan, (3) memfasilitasi penyediaan peralatan pengemasan yang memadai untuk menghasilkan produk olahan (kemasan) kacang sangrai yang memenuhi standar dan keinginan konsumen, (4) meningkatkan pendapatan masyarakat pelaku usaha kacang sangrai di desa Kinali Satu. Metode pendekatan yang diterapkan dalam pelaksanaan kegiatan deseminasi produk teknologi kepada masyarakat ini yaitu kombinasi metode Pilot Project penerapan teknologi pengeringan. Pendekatan pembelajaran yang digunakan adalah pendekatan partisipatif (Participatory Rural Appraisal) dan pemahaman desa secara cepat (Rapid Rural Appricial). Melalui program deseminasi produk tenologi kepada masyarakat maka (1) telah terfasilitasi satu unit pengolahan kacang tanah (mesin pengering) kacang tanah dan bahan pangan lainnya, (2) terimplementasi teknologi pengeringan yang dapat menghasilkan produk kacang dengan kadar air yang memenuhi standar, dan produk kacang sangrai bebas dari kandungan toksin, (3) terfasilitasi proses pengemasan kacang tanah yang memenuhi standar kemasan, (4) meningkatnya pengetahuan masyarakat tentang teknologi pascapanen terutama teknologi proses pengeringan dan pengemasan yang memenuhi standar kualitas dan kesehatan dan, (5) meningkatnya pendapatan masyarakat pelaku usaha kacang sangrai di desa Kinali Satu.
\end{abstract}

Kata Kunci: pengering, kacang tanah, sangray.

\section{PENDAHULUAN}

\section{Analisis Situasi}

Desa Kinali Satu Kecamatan

Kawangkoan merupakan salah satu wilayah dikenal sebagai sentra usaha pascapanen kacang tanah atau lebih dikenal sebagai kacang "tore" atau "kacang sangrai" dan berbagai produk ikutan olahan lainnya. Pengolahan kacang sangrai merupakan pekerjaan bagi sebagian besar masyarakat Kinali Satu yang sudah berlangsung sejak puluhan tahun dan secara turun temurun dilakoni oleh masyarakat dalam skala rumah tangga dan kelompok dengan skala yang berbeda-beda. Walaupun demikian terdapat sejumlah permasalahan yang dihadapi oleh setiap keluarga atau kelompok yang mengelola usaha kacang sangrai tersebut, yaitu sangat lambat pertumbuhan usaha pengolahan kacang tanah walaupun usaha tersebut telah dilakoni bertahun-tahun oleh masyarakat. 
Berdasarkan hasil pengamatan salah satu faktor penentu adalah rendahnya pengetahuan dan keterampilan dalam mengolah produk kacang tanah pascapanen. Faktor lainnya yang tidak kalah penting adalah bahan baku yang sering tidak tersedia secara kontinyu dan terkadang berfluktuasi. Hal ini disebabkan di samping lahan yang semakin terbatas, juga menurunnya produktivitas lahan akibat praktek usaha tani yang monokultur dan tingginya intensitas penggunaan lahan. Permasalahan mendasar yang tidak dapat dihindari adalah pada saat panen tiba musim hujan, maka hasil panen komoditi pertanian seperti kacang tanah selalu mengalami kerusakan atau pembusukan yang pada gilirannya dapat menurunkan kualitas produksi. Kerusakan yang terjadi dan berkali-kali dialami oleh patani kacang tanah di desa Kinali dan desa-desa lainnya sebagai sentra kacang tanah dapat mencapai 30 - 40 persen dari total produksi. Hal ini dikarenakan musim hujan lebih sering terjadi di wilayah Kawangkoan. Rata-rata 13 hari hujan pada musim panas dengan curah hujan $177.53 \mathrm{~mm}$ dan 23 hari musim hujan (November - April) dengan curah hujan rata-rata mencapai 244,53 mm dalam sebulan dengan ersentase temperatur udara absolute mencapai 93,93 persen per bulan dan rata-rata kelembaban minimum mencapai 80,50 persen per bulan.

Hal ini disebabkan karena kelembaban yang tinggi pada musim hujan sangat mendukung pertumbuhan jamur 46 penghasil mikotoksin. Salah satu upaya yang dapat dilakukan untuk mengatasinya adalah menerapkan teknologi penanganan pascapanen yang baik. Sebagaimana diketahui bahwa penanganan pascapanen kacang tanah meliputi pemipilan, sortasi, pengeringan, dan penyimpanan. Penanganan ini diperlukan karena kacang tanah tetap mengalami metabolisme dan respirasi yang menyebabkan perubahan sifat fisik, kimia, mikrobiologi.

Selama ini tidak ada cara lain yang dapat dilakukan oleh patani kacang di Kinali dan desa lainnya sebagai sentra produksi kacang tanah di Kecamatan Kawangkoan selain penjemuran yang digelar terbuka mengandalkan panas dari matahari. Kelemahan proses pengeringan dengan penjemuran di bawah sinar matahari antara selain tidak dapat tersedia secara kontinyu, juga apabila dijemur dibawah terik matahari tidak dapat terkontrol penurunan kadar air pada batas aman. Sesungguhnya dengan melakukan pengeringan, di samping kadar air kacang tanah akan mengalami penurun-an sampai batas aman dan dapat menjaga kualitas produk olahan, juga paling utama dalam proses pengeringan bahan pangan seperti kacang tanah adalah untuk mencegah tumbuhnya mikroorganisme terutama jamur yang dapat menghasilkan toksin yang membahayakan kesehatan konsumen. Ka-dar air biji kacang tanah saat panen berki-sar antara 35 - 50\%, dimana pada kondisi tersebut jamur akan tumbuh 
dan menghasilkan racun (Diedhiou et al.,2012; Darko, 2016).

Permasalahan lain yang juga menjadi faktor penghambat perkembangan usaha pengolahan kacang tanah adalah bagaimana menjaga kualitas dan kelayakan produk olahan pascapanen kacang tanah. Sebagaimana diuraikan di atas bahwa kacang tanah dengan mudah terserang cendawan dan terkontaminasi aflatoksin apabila kegiatan pascapanen seperti pengeringan dan penyimpanan tidak dilakukan secara layak. Kegiatan pengeringan sangat erat kaitannya dengan kadar air sebelum disimpan, dan sangat mempengaruhi kualitas biji setelah penyimpanan (Yeyen dan Purwaningsih (2014). Cara dan sarana penanganan pascapanen termasuk pengemasan untuk penyimpanan kacang tanah yang tidak layak dapat berpengaruh terhadap kualitas kacang tanah. Sesungguhnya jika produk ini dikemas dalam berbagai ukuran dan kemasannya menarik, maka harganya akan lebih tinggi. Sering kondisi yang dialami oleh mitra adalah walaupun produk sangrai sudah memenuhi standar (dipilah kacang yang berkualitas), tetapi bentuk kemasannya tidak begitu menarik, sering konsumen tidak tertarik untuk membelinya.

Dari hasil survey dan wawancara dengan kelompok Mitra, biasanya mereka menjual produk kacang sangrai per liter Rp 8.000, sementara pedagang yang menjual langsung ke konsumen dalam kemasan terstandar dalam ukuran $0,5 \mathrm{~kg}$ atau sekitar
2 liter dengan kemasan plastik bening dapat dijual menjadi Rp.30.000,- per bungkus/pak. Sehingga pedagang pengemas boleh mendapatkan keuntungan sekitar Rp 14.000,- per pak. Hal ini memberi gambaran bahwa kelompok mitra lebih banyak memberikan keuntungan kepada para pedagang antara atau pengemas.

\section{Permasalahan Mitra}

Berdasarkan justifikasi pengusul bersama mitra, maka permasalahan prioritas yang disepakai untuk diselesaikan dalam kegiatan deseminasi teknologi ini yaitu :

(1) Proses pengeringan kacang masih dilakukan secara tradisional dan masih sangat tergantung pada sinar matahari, sehingga ketika musim hujan produk pertanian terutama kacang tanah mengalami kerusakan akibat tidak terjemur karena hanya mengandalkan sinar matahari. Bahkan dengan penjemuran matahari sering menghasilkan produk yang tidak merata kadar airnya.

(2) Kualitas hasil olahan kacang sangrai (pengeringan) tidak merata karena proses penjemuran dibawah sinar matahari sulit dikontrol kadar air yang memenuhi syarat higienis, terlebih ketika musim hujan tidak jarang produksi kacang tanah mengalami kerusakan mencapai 30-40 persen.

(3) Kurangnya informasi dan pengetahuan masyarakat tentang teknologi pascapanen terutama teknologi proses penge- 
ringan dan pengemasan yang memenuhi standar kualitas dan kesehatan.

(4) Terjadi penurunan produksi kacang tanah olahan (kering) pada saat musim hujan.

(5) Masih rendah tingkat pendapatan masyarakat akibat harga juah produk petani belum sesuai dengan harga pasar.

\section{Tujuan}

(1) Memfasilitasi dan menerapkan teknologi pengeringan dengan menggunakan sistem Rotary Dryer konveksi paksa, menggunakan energi panas berbahan bakar gas yang dapat dikontrol secara terus menerus secara merata.

(2) Memfasilitasi upaya peningkatan pengetahuan dan keterampilan masyarakat tentang teknologi pascapanen terutama teknologi proses pengeringan dan pengemasan kacang tanah yang memenuhi standar kualitas dan kesehatan.

(3) Meningkatkan produksi kacang tanah hasil olahan (pengeringan) dan produksi kacang sangray kemasan.

(4) Meningkatkan ekonomi pendapatan masyarakat melalui usaha pengolahan kacang sangrai.

\section{METODE PELAKSANAAN}

\section{Metode dan Tahapan Penerapan \\ Teknologi}

Metode pendekatan yang diterapkan dalam pelaksanaan kegiatan deseminasi produk teknologi kepada masyarakat ini 48 yaitu kombinasi pendekatan Pilot Project dengan partisipatif (Participatory Rural Appraisal) dan pemahaman desa secara cepat (Rapid Rural Appricial). Melalui pendekatan PRA dan RRA diharapkan dapat memecahkan masalah utama yang dihadapi oleh kelompok yaitu rendahnya atau tidak meratanya kualitas kacang tanah akibat proses pengeringan yang hanya mengandalkan sinar matahari dan terlebih ketika tiba musim hujan sangat signifikan kerusakan yang dapat diakibatkan dimana sebagian hasil kacang tanah akan mengalami pembusukan dan jamuran sehingga dengan mudah terkontaminasi bahan toksin yang dihasilkan oleh mikroba.

\section{Deskripsi Teknologi yang Didiseminasi}

Sebagaimana diuraikan sebelumnya bahwa teknologi yang diterapkan adalah sistem pengering konveksi paksa dengan sumber energi panas yang berasal dari pembakaran bahan bakar gas (LPG). Proses kerja dari mesin pengering ini adalah dengan memanfaatkan energi panas yang dihasilkan dari pembakaran gas dengan dengan cara melakukan perpindahan panas konveksi paksa dengan fan blower ke bawah bak pengering yang kemudian memanaskan secara tidak langsung kacang tanah yang dikeringkan. Proses pemanasan dikendalikan dengan adanya thermostat sebagai alat pengatur atau pemerata panas (suhu) sehingga panas yang dinginkan dalam proses pengering tetap terjaga dengan baik tanpa harus khawatir ada satu bagian objek 
yang kurang panas atau berlebihan, disamping itu alat ini juga dilengkapi dengan timer control untuk mengatur lamanya waktu pengeringan yang diinginkan sehingga mesin bisa berhenti beroperasi secara otomatis ketika sudah mencapai waktu yang diinginkan tersebut. Alat pengering ini berkapasitas 500-1000 kg dengan waktu proses selama 2-3 jam. Komponen utama alat pengering kacang tanah ini adalah tungku pemanas menggunakan kompor LPG regulator tekanan tinggi, blower, control unit, box atau rak tempat menaruh produk yang dikeringkan. Keuntungan atau keunggulan teknologi ini adalah proses pengeringan dapat dilakukan secara singkat sehingga dapat mencegah kerusakan kacang tanah terutama mencegah kontaminan dan menghambat proses enzimatis yang dapat menurunkan kualitas produksi. Pada musim hujan alat ini sangat dibutuhkan dalam proses pengeringan sehingga kacang tanah terhindar dari proses percambaan yang menurunkan kualitas produk dikarenakan tidak ada cahaya matahari.

\section{Persiapan Pelaksanaan Kegiatan}

Langkah yang dilakukan oleh tim kerja pelaksana deseminasi produk teknologi adalah melakukan persiapan yang diawali dengan pembahasan program dan langkahlangkah kerja tim mulai dari pembagian tugas dan tanggungjawab berdasarkan kompetensi masing-masing anggota tim. Pada tahapan ini juga dilakukan pemantapan pemahaman atau penyamaan persepsi tentang program yang dijalankan oleh tim itu sendiri serta persiapan bahan dan alat terutama proses perakitan unit pengeringan yang digunakan dalam pelaksanaan kegiatan deseminasi produk teknologi.

\section{Sosialisasi}

Kegiatan sosialisasi merupakan salah satu tahapan penting dalam menyampaikan hal-hal yang berkaitan dengan program dan kegiatan deseminasi teknologi pengolahan kacang tanah, terutama terkaita dengan proses pengeringan. Sehingga kegiatan ini lebih ditekankan kepada pemberian pemahaman dan pengertian kepada masyarakat tentang pentingnya kegiatan deseminasi teknologi kepada masyarakat dalam upaya perbaikan proses produksi kacang tanah terutama dalam kaitan dengan aspek pengeringan. Kegiatan tersebut menyangkut transformasi gambaran ilmu pengetahuan dan teknologi dalam upaya memecahkan masalah yang dihadapi oleh masyarakat petani dalam usaha pengolahan kacang tanah untuk menghasilkan kacang sangrai yang berkualitas dan memiliki daya saing pasar. Dalam kegiatan sosialisasi dijelaskan pula tentang teknologi yang diterapkan kepada masyarakat terutama berkaitan dengan perbaikan produksi kacang tanah melalui desiminasi teknologi pengeringan dan pengemasan kacang tanah. Metode sosialisasi disini tidak hanya memberikan informasi secara tunggal tetapi dilakukan 
melalui berbagai pendekatan terutama melalui pendekatan PRA dan RRA untuk memberi pemahaman tentang rasa memiliki kegiatan tersebut. Rasa memiliki dapat ditanamkan antara lain melalui pendekatan partisipatif, dimana masyarakat atau anggota kelompok dapat memberi diri untuk berpartisipasi secara aktif melalui kegiatan proses implementasi kegiatan.

\section{Implementasi Teknologi}

Implementasi teknologi mencakup kegiatan praktek penggunaan peralatan pengering yang telah dirancang dan dihasilkan dan proses produksi (pengeringan) yang dilaksanakan langsung oleh warga belajar dengan dituntun langsung oleh tim pelaksana kegiatan deseminasi teknologi. Untuk efektifnya pelaksanaan dan tercapainya luaran kegiatan maka implementasi teknologi bertolak permasalahan mendasar yang telah disepakati bersama yaitu menerapkan teknologi pengering dengan konveksi paksa sumber energi panas yang berasal dari pembakaran bahan bakar gas (LPG) untuk mengatasi masalah kerusakan dan meningkatkan kualitas produk olahan akibat proses pengeringan yang konvensional yang hanya mengandalkan sinar matahari dan terutama mengatasi proses pengeringan kacang tanah ketika musim hujan.

\section{HASIL DAN PEMBAHASAN}

Sebagaimana diuraikan sebelumnya bahwa melalui program deseminasi produk teknologi kepada masyarakat dalam rangka 50 mengaplikasikan teknologi pengolahan kacang tanah di desa Kinali Satu Kecamatan Kawangkoan maka telah terfasilitasi penyediaan satu unit teknologi pengeringan dan telah terlaksana dengan baik. Terdapat sejumlah manfaat penting yang telah diperoleh melalui program deseminasi produk teknologi dalam hal ini teknologi proses pengeringan dan pengemasan kacang tanah. Beberapa kriteria keberhasilan berasarkan manfaat yang diperoleh (outcome) yaitu: adanya peningkatan kapasitas sumberdaya mitra terutama adanya peningkatan pemahaman dan penguasaan pengetahuan dan teknologi proses pengolahan terutama pengeringan dan pengemasan serta manajemen pemasaran produk olahan kacang tanah. Berdasarkan hasil evaluasi awal program deseminasi produk teknologi bagi masyarakat bahwa sebagian besar yaitu mencapai 90 persen masyarakat tidak mengenal teknologi pengolahan (pengeringan) kacang tanah dengan memanfaatkan energi gas sebagai sumber panas dan tidak ada upaya yang dilakukan selama ini untuk memperbaiki proses pengolahan terutama proses pengeringan ketika panen dan musim hujan tiba. Namun melalui program deseminasi produk teknologi pengeringan, maka sumberdaya masyarakat mengalami peningkatan signifikan yaitu mendapatkan pengetahuan dan keterampilan pemanfaatan fasilitas pengeringan yang serba guna tersebut.

Fungsi dan manfaat penting dari program deseminasi produk teknologi lain- 
nya adalah adanya peningkatan produktivitas (kuantitas dan kualitas produksi) kacang tanah atau kacang sangrai. Sebagaimana diketahui bahwa sebelum adanya implementasi teknologi pengeringan ini, masyarakat mengalami kerugian yang signifikan terutama dari tingginya tingkat kerusakan akibat tidak dapat,melakukan proses pengeringan kacang tanah dan bahan pangan lainnya ketika tiba musim hujan. Tingkat kerusakan bahan baku kacang tanah ketika panen dan musim hujan tiba dapat mencapai 30 - 40 persen, dan bahkan dapat mencapai 50-55 persen pada kasus tertentu. Kondisi ini sudah dialami bertahun-tahun dan terutama pada musim penghujan yang selalu terjadi pada ahir tahun sampai awal tahun. Selama ini pula praktis tidak ada upaya yang dilakukan untuk mengatasi masalah tersebut.

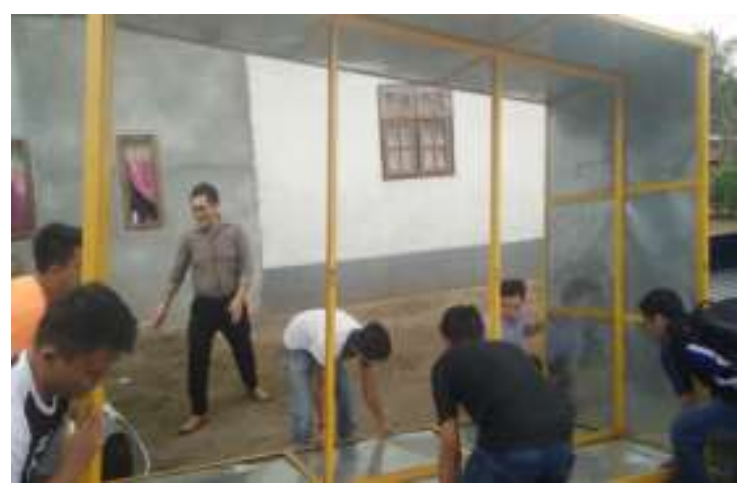

Gambar 1. Aktivitas proses konstruksi mesin pengering kacang tanah.

Langkah yang dapat dilakukan oleh masyarakat adalah membatasi jumlah atau volume bahan baku (kacang tanah) basah atau yang baru selesai panen atau menunda masa panen. Hal ini tentunya sangat merugikan petani pembudidaya kacang karena penundaan masa panen selain serangan hama, juga biji kacang tanah sudah ada yang bertumbuh tunas atau membusuk, semantara pada satu sisi setiap akhir tahun permintaan atau konsumsi kacang tanah mengalami peningkatan yang signifikan. Berbagai penelitian menunjukkan bahwa penundaan panen khususnya pada saat musim hujan selain dapat menurunkan mutu akibat perubahan sifat fisik, biologi dan kimia, juga aktivitas mikrobiologi juga meningkat secara signifikan yang mengakibatkan pembusukan dan peningkatan kontaminasi aflatoksin (Arunyanark et al., 2009; Biljana et al., 2013; Yeyen dan Purwaningsih, 2014).

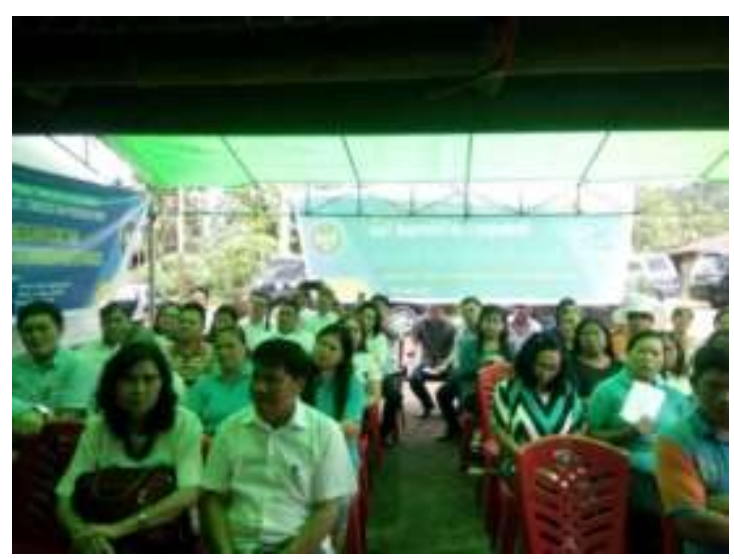

Gambar 2. Peserta disemniasi selain dihadiri oleh masyarakat, juga seluruh perangkat desa Kinali Satu dan Pemerintah Kecamatan Kawangkoan.

Langkah klasik yang selama ini ditempuh dalam memenuhi kebutuhan konsumsi adalah dengan mendatangkan kacang tanah yang sudah kering dari luar daerah seperti dari pulau Jawa atau Sulawesi Selatan dengan harga yang 
melambung tinggi. Bahkan ditengarai bahwa tingginya tingkat kerusakan pascapanen tersebut turut menyumbang terus menurunnya produksi kacang tanah Sulawesi Utara dari tahun 2011 yang mencapai 9.049 ton dan tahun 2015 hanya mencapai 3.971 ton (Anonimus, 2016). Fungsi dari fasilitas pengeringan ini yang tidak kalah penting adalah dengan kapasitas yang mencapai 2.5 ton sekali proses pengeringan dan dengan tingkat keseragaman serta lama waktu pengeringan yang hanya \pm 2 jam tentunya sangat membantu mengatasi kerusakan kacang tanah dan komoditi pertanian lainnya.

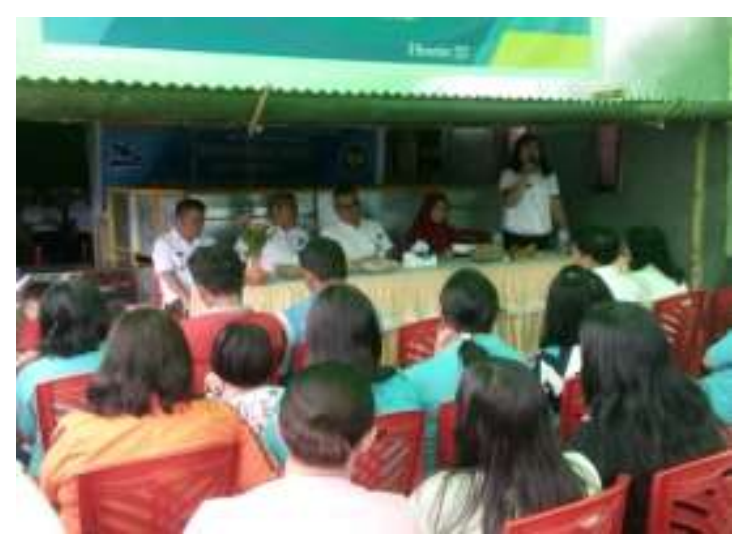

Gambar 3. Apresiasi dan sambutan Camat Kawangkoan.

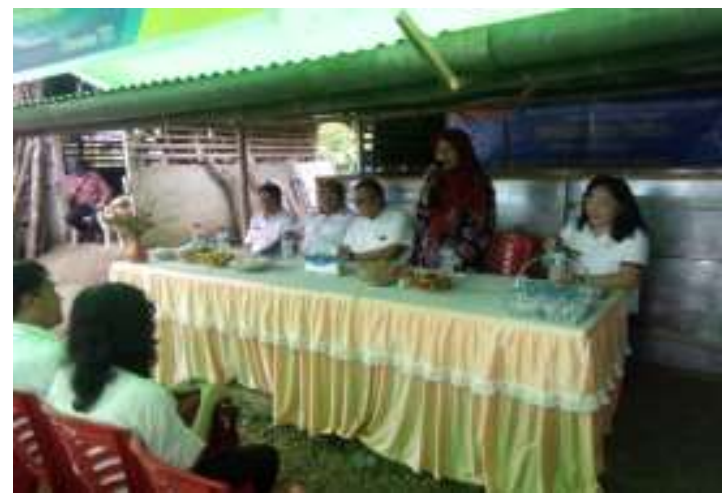

Gambar 4. Sambutan Dr Mustangimah MSc, Kasubdit Peningkatan Kapasitas Riset Perguruan Tinggi DRPM Kemenristekdikti.

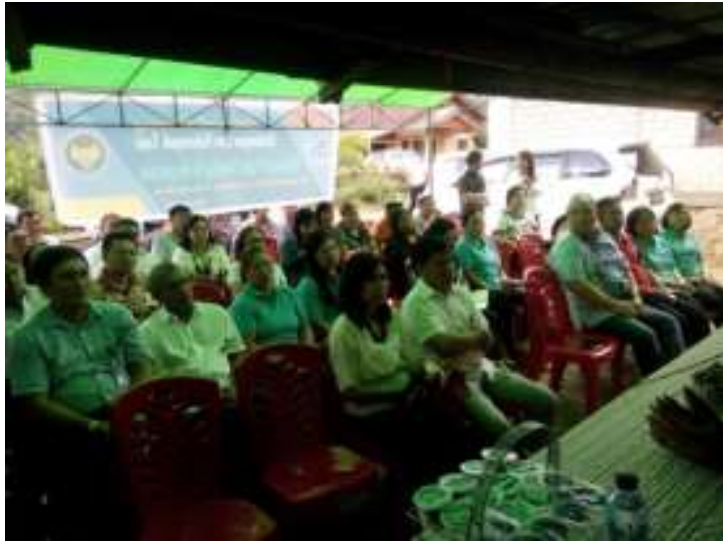

Gambar 5. Peserta deseminasi mencermati dengan serius penyampaian dari Ibu Mustangimah.

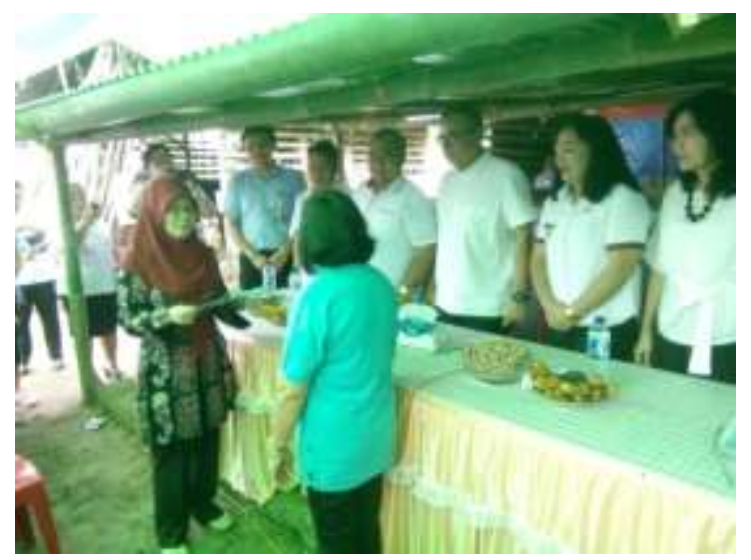

Gambar 6. Penyerahan produk teknologi kepada masyarakat oleh Ibu Mustangimah kepada ketua kelompok tani.

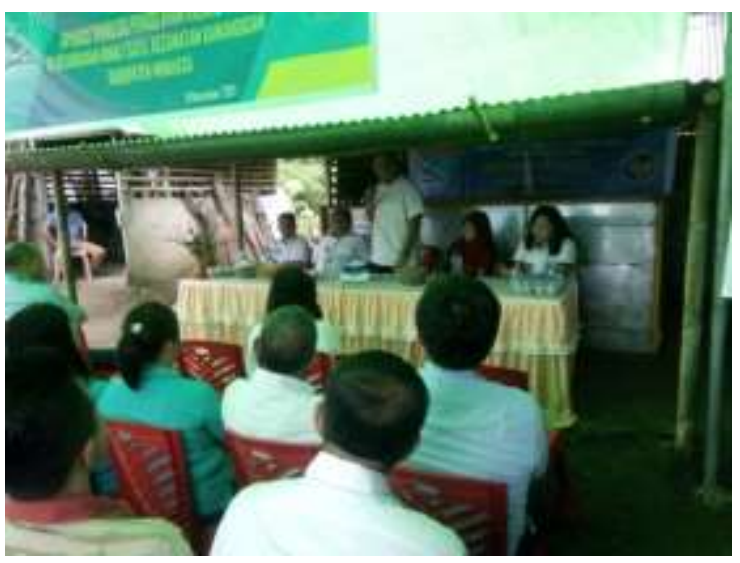

Gambar 7. Sambutan oleh Anggota DPR RI Dapil SULUT, Bapak Bara Hasibuan.

Melalui program deseminasi produk teknologi kepada masyarakat dalam upaya aplikasi teknologi pengolahan kacang tanah 
di desa Kinali Satu Kecamatan Kawangkoan maka telah dicapai keluaran (output) meliputi:

(1) telah terfasilitasi penyediaan paket teknologi berupa terbangunnya satu unit instalasi pengolahan kacang tanah yang terdiri dari satu unit ruang produksi. Selama ini proses produksi hanya dilakukan dalam ruang sederhana yang menyatu dengan dapur pemlik rumah.

(2) Melalui program dan kegiatan deseminasi produk teknologi kepada masyarakat, telah terfasilitasi satu unit mesin pengering dan implementasi teknologi proses pengeringan yang dapat mengurangi kerusakan dan kontaminasi toksin pada kacang tanah terutama saat panen tiba musim hujan.

(3) Dalam rangka menjawab permasalahan mitra melalui deseminasi produk teknologi, maka salah satu keluaran yang dicapai yaitu adanya peningkatan pengetahuan dan keterampilan masyarakat tentang teknologi pascapanen terutama teknologi proses pengeringan yang memenuhi standar kualitas dan kesehatan.

(4) Meningkatnya hasil proses pengeringan kacang tanah melalui penerapan teknologi pengering kacang tanah. Melalui proses pengeringan dapat menekan kerusakan kacang tanah dengan tingkat capaian 95 persen.

Secara ekonomi jika dibandingkan dengan cara pengeringan tradisional (di dijemur di sinar matahari), penggunaan alat pengering ini dapat menghemat waktu pengeringan 2 hingga 3 hari dengan mutu kacang tanah lebih baik. Hasil analisis kelayakan finansial menunjukkan bahwa pada tingkat harga alat (termasuk mesin penggerak, motor pengaduk, dan dudukan mesin) Rp 35.000.000/unit, kapasitas efektif pengeringan 500 - $1000 \mathrm{~kg}$ kacang tanah /jam/2 orang operator, upah dua orang operator Rp. 60.000/hari, ongkos jasa pengeringan Rp. 30/kg (sekitar 1\% dari harga eceran kacang tanah polong kering Rp3.000/kg) dan jam kerja efektif 120 jam/th; diperoleh biaya pokok alat $\mathrm{Rp}$. $19,3 / \mathrm{kg}$, titik impas 45 ton/th, waktu pengembalian modal 1 tahun, nilai keuntungan sekarang (NPV) Rp. 2.100.000, nisbah keuntungan dengan biaya $(\mathrm{B} / \mathrm{C})$ 1,2 dan tingkat pengembalian modal 61,5\%. Dengan demikian teknologi pengering kacang tanah dianggap layak dikembangkan dalam membantu petani dalam meningkatkan nilai ekonomi bagi masyarakat pelaku usaha pengolahan kacang tanah.

Salah satu kontribusi dan dampak ekonomi dan sosial dari program deseminasi produk teknologi kepada masyarakat ini adalah adanya peningkatan nilai tambah produk, mutu, dan daya saing usaha kacang sangrai. Nilai tambah yang diperoleh melalui implementasi produk teknologi pengering ini antara lain terukur juga dari adanya peningkatan jumlah produk kacang yang kering dari lazimnya 
hanya 60-65 persen mengalami peningkatan mencapai 95 persen pada saat musim hujan yang terjadi belakangan ini. Selain dapat menekan atau mengeleminasi tingkat kerusakan, program deseminasi teknologi pengeringan ini dapat mempercepat atau mempersingkat waktu dan proses pengeringan. Dampak sosial yang sangat nyata dan dirasakan oleh masyarakat antara lain telah menciptakan lapangan kerja baru juga bagi masyarakat serta merekatkan dan membangun kembali jiwa gotong royong dan saling membantu antar anggota masyarakat petani. Hal ini terlihat ketika musim hujan, maka fasilitas pengeringan yang telah dihasilkan tersebut dapat digunakan oleh kelompok pengolah kacang tanah lainnya.

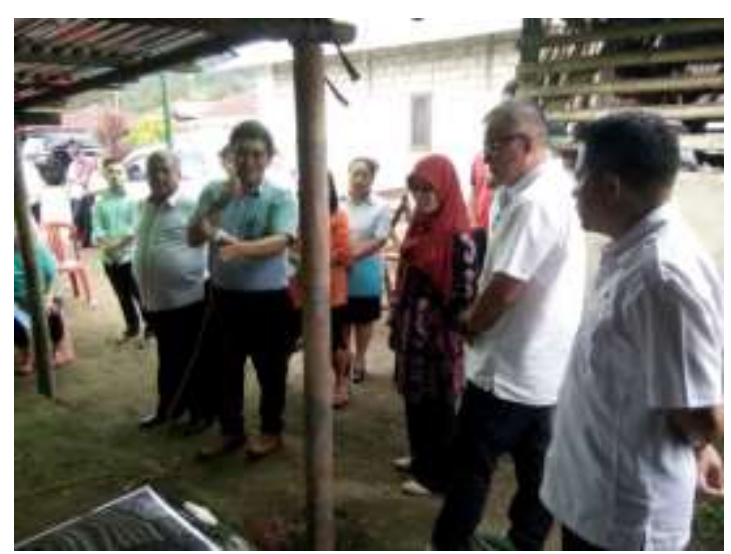

Gambar 8. Demonstrasi penggunaan mesin pengering.

Salah satu kontribusi penting kehadiran program deseminasi produk teknologi kepada masyarakat terhadap sektor lain adalah fungsi dan manfaat teknologi pengering tersebut tidak saja digunakan untuk pengeringan kacang tanah, tetapi juga telah digunakan dalam proses pengeringan berbagai bahan atau produk pertanian dan tanaman pangan basah yang memerlukan proses pengeringan. Saat ini mesin pengering tersebut tidak saja digunakan oleh kelompok dan masyarakat sekitar untuk pengeringan kacang tanah tetapi juga untuk pengeringan kacang merah, kedelai dan jagung serta aneka komoditi pangan lainnya.

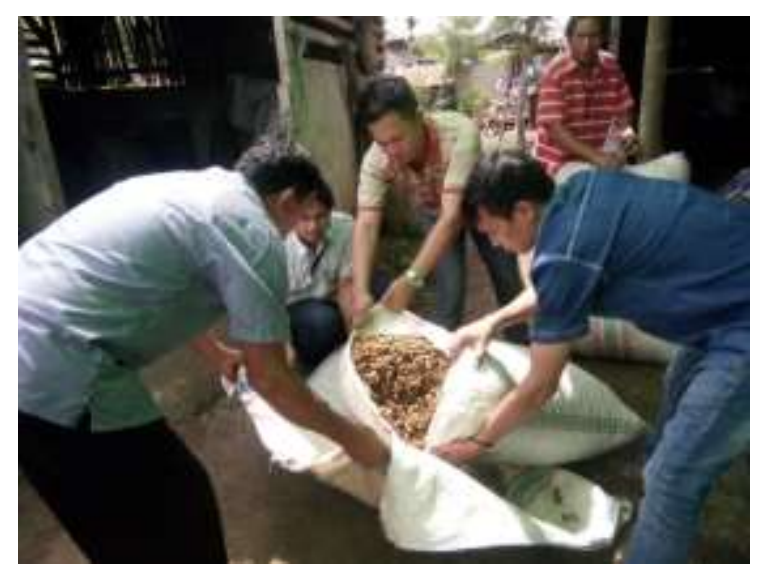

Gambar 9. Persiapan bahan baku (kacang tanah) yang akan dikeringkan.

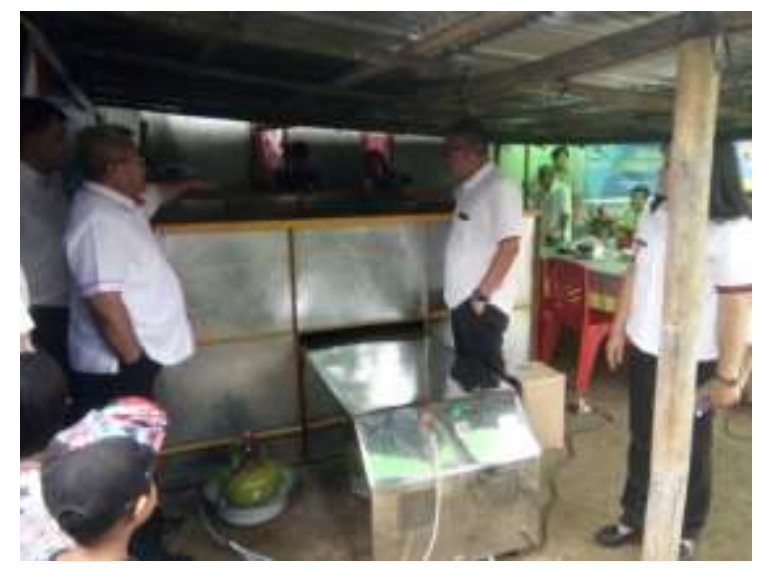

Gambar 10. Demonstrasi proses pengeringan kacang tanah disaksikan oleh Ibu Mustangimah dan Bapak Bara Hasibuan.

Kontribusi yang tidak kalah penting kehadiran instalasi pengeringan yang 
difasilitasi lewat program deseminasi produk teknologi kepada masyarakat ini adalah telah menjadi media pembelajaran bagi masyarakat secara umum. Pada umumnya masyarakat datang belajar terutama ingin memahami teknologi tersebut dari segi konstruksi dan efisiensi pemanfaatan teknologi serta kegunaannya serba guna dan dirasa sangat membantu masyarakat terutama dalam proses pengeringan berbagai komoditi pertanian.

Melalui program deseminasi produk teknologi kepada masyarakat ini telah terfasilitasi pula teknologi pengemasan kacang tanah. Sebagaimana diuraikan sebelumnya bahwa salah satu permasalahan mendasar adalah rendahnya nilai tambah dari usaha kacang kacang tanah karena selama ini kelompok masyarakat hanya sebagai penyedia kacang tanah yang sudah dikeringkan dan disangrai. Sementara proses pengemasan dilakukan oleh pedang penampung yang kemudian mengemas dengan kemasan standar dan memenuhi keinginan konsumen. Melalui proses pengemasan tersebut pedagang penampung mendapatkan keuntungan yang sangat signifikan. Oleh karena itu melalui program deseminasi produk teknologi kepada masyarakat telah difasilitasi usaha pengemasan kacang tanah (sangrai) dalam berbagai ukuran. Selama ini kelompok Mitra menjual kacang tanah yang sudah diolah (dikeringkan dan sangrai) ke pedagang pengumpul rata-rata per bulan sebanyak
750 liter dengan harga per liter berkisar Rp.7.500 sampai dengan Rp.10.000 dengan nilai jual berkisar antara Rp.5625.000 sampai Rp.7.500.000 per bulan. Namun dengan terfasilitasinya proses pengemasan yang langsung dilakukan oleh kelompok maka sebagian besar produk olahan kacang tanah telah dapat langsung diproduksi dan dipasarkan dalam bentuk kemasan dengan harga Rp.12.500 sampai dengan Rp.13.000 per liter dengan nilai jual Rp.9.375.000 sampai Rp.9.750.000 per bulan. Nilai jual tersebut jika dikurangi biaya produksi ratarata mencapai 65 persen, maka pendapatan bersih dari kelompok berkisar Rp.3.281.250 sampai Rp.3.412.000. Diharapkan dengan terfasilitasinya proses pengeringan kacang tanah maka pada gilirannya akan meningkatkan volume produksi kacang olahan (sangray) yang tebntunya akan berdampak pada peningkatan nilai tambah ekonomi dari produk kacang tanah olahan bagi kelompok pengolah kacang tanah.

\section{KESIMPULAN DAN SARAN}

\section{Kesimpulan}

Melalui program deseminasi produk teknologi bagi masyarakat dalam rangka aplikasi teknologi pengolahan kacang tanah di desa Kinali Satu Kecamatan Kawangkoan Minahasa dapat disimpulan bahwa:

(1) Telah terfasilitasi satu unit pengolahan kacang tanah (mesin pengering) kacang tanah dan bahan pangan lainnya.

(2) Telah terimplementasi teknologi pengeringan yang dapat menghasilkan 
produk kacang dengan kadar air yang memenuhi standar, dan produk kacang sangrai bebas dari kandungan toksin.

(3) Terfasilitasi proses pengemasan kacang tanah yang memenuhi standar kemasan.

(4) Meningkatnya pengetahuan masyarakat tentang teknologi pascapanen terutama teknologi proses pengeringan dan pengemasan yang memenuhi standar kualitas dan kesehatan.

(5) Meningkatnya pendapatan masyarakat pelaku usaha kacang sangrai di desa Kinali Satu.

\section{Saran}

Diperlukan pendampingan secara kontinyu dari berbagai pihak terutama dari Perguruan Tinggi sehingga tumbuh usaha pedesaan yang mandiri terutama dalam pengolahan kacang tanah dan produk olaha lainnya.

\section{UCAPAN TERIMA KASIH}

$$
\text { Kegiatan Pengabdian kepada }
$$

Masyarakat ini dibiayai melalui Program Diseminasi Produk Teknologi kepada Masyarakat, Direktorat Riset dan Pengabdian Masyarakat, Direktorat Jenderal Penguatan Riset dan Pengembangan,
Kementerian Riset Teknologi, dan Pendidikan Tinggi, Jakarta.

\section{KEPUSTAKAAN}

Anonimus, 2016. Produksi Kacang Tanah di Sulawesi Utara. Badan Pusat Statistik Provinsi Sulawesi Utara, Tahun 2017.

Arunyanark A., S. Jogly, S. Wongkaew, C. Akkasaeng, G. C. Wright and A. Patanothai. 2009. Association between aflatoxin contamination and drought tolerance traits in peanut. Field Crops Res. 114:14-22.

Biljana S., D. Z. Hajrulai, Musliu, U. Risto and P. Sekulovski. 2013. Occurence of aflatoxins in peanuts and peanut products determined by liquid chromatography with fluorescence detection. J. Nat Sci. Matica Nov Sad. 124:27-35.

Diedhiou, PM., B. Fatoumata, A Kane and N. Mbaye. 2012. Effect of different cooking methods on aflatoxin fate in peanut products. Afr. J. Food Sci. Technol. 3 (2) : $53-58$.

Darco B. C., 2016. Effect of storage conditions on Aspergillus growth and aflatoxin production in peanuts. A Studi in Gana. Disertation Submitted to the Faculty of the Virginia Polytechnic Institute and State University.

Yeyen P. W dan Purwaningsih. 2014. Mutu fisik kacang tanah dengan cara pengeringan dan musim panen berbeda. Prosiding Seminar Hasil Penelitian Tanaman Aneka Kacang dan Umbi. Halaman 707 - 713. 